\title{
Vista de conjunto de la contractilidad uterina en el estado grávido puerperal
}

\author{
EL DOLOR UTERINO
}

Capítulo final del trabajo "Fisiopatología de la Con_ tracción Uterina y sus aplicaciones en la Clínica Obstétrica". Por los doctores Hermógenes Alvarez (Profesor de Clínica Obstétrica y Ginecológica) y Roberto Caldeyro Barcia (Profesor Agregado de Fisiología). Facultad de Medicina de Montevideo.-Uruguay.

Durante todo el estado grávido puerperal (embarazo, prepar_ to, parto, alumbramiento y post_alumbramiento) el útero presenta una actividad contractil rítmica, nunca interrumpida. Pero en ca_ da período las características de esa contractilidad son diferentes, adecuándose a las funciones que debe cumplir. En el embarazo las contracciones son de pequeña intensidad y de frecuencia ele_ vada, para facilitar la circulación uterina sin provocar la salida del feto; las ondas más pequeñas corresponden a contracciones lo_ calizadas; las ondas mayores (Braxton Hicks) a contracciones generalizadas pero que carecen del Triple Gradiente Descendente. En el preparto se produce la maduración de las fibras, cuya con_ centración en Actomiosina aumenta, y les permite desarrollar con. tracciones cada vez más fuertes; van adquiriendo además el Triple Gradiente Descendente, que en parte se debe a que la Acto. miosina aumenta más en las partes altas del utero que en las par. tes bajas (Naeslund y Sneliman, 1951). La transformación de la contractilidad del embarazo en la del parto puede hacerse en dos formas diferentes. En el parto las contracciones tienen gran intensidad y Triple Gradiente Descendente (para dilatar el cuello y expulsar el feto) y frecuencia baja (para no causar anoxia). En el período de expulsión, a la presión desarrollada por el útero, se suma la presión ejercida por las paredes abdominales (pujos); estos se efectúan generalmente durante el acmé de las contraccio_ nes uterinas ( 2 o 3 pujos en cada una) y desarrollan presiones de 
40 a $60 \mathrm{~mm}$. Hg; son más bruscos y de menor duración que las contracciones del útero. En el alumbramiento las contracciones son similares a las del parto, aunque el tono es ligeramente más bajo por la reducción de volumen experimentada; las contraccio_ nes son algo más intensas. En el post-alpmbramiento se produce una gran disminución en la frecuencia de las contracciones, y en la velocidad de propagación de la onda, la que adquiere un carácter peristáltico, que la vueive muy eficaz para expulsar coágulos y loquios. Durante el puerperio la contractilidad se va modifican. do progresivamente hasta adquirir los caracteres propios del útero no grávido. Como éste presenta también una contractilidad rít. mica permanente podemos afirmar que durante todo el per odo de actividad sexual de la mujer, desde ia pubertad hasta meno. pausia, el útero está siempre contrayéndose rítmicamente.

\section{El dolor uterino}

En Obstetricia Dolor y Contracción uterina son dos conceptos que siempre han sido intimamente asociados, de tal modo que es corriente emplear el término "dolores" para referirse a las "contracciones". Dexeus Font (1949), manifiesta que "el dolor sigue a la contracción como la sombra al cuerpo"; esta es la opinión ge. neralmente aceptada por la mayoria de los obstetras.

Sin embargo Chassar Moir (1939) ha dado argumentos muy sólídos que demuestran que la contracción uterina es indolora en sí misma; y que el dolor que acompaña a cada contracción del parto se debe, en el período de dilatación a la distensión que las contracciones causan en ei cuello uterino y en el segmento inferior; y en el perícdo de expulsión a la distensión de la vagina y del pe. riné. Esto último queda demostrado por el hecho de que el blo_ queo anestésico del pudendo interno suprime los dolores del período expulsivo; el pudendo interno no inerva al útero y sí a ia va_ gina y al periné.

De acuerdo con las más modernas investigaciones (Bonica, 1953), se acepta que la contracción normal, fisiológica, de los músculos viscerales, es indolora. $Y$ que las dos grandes causas de dolor visceral son:

1) la distensión más o menos brusca; 2) la anoxia prolongada en un músculo que está contrayendo. Estos conocimientos se apli_ can perfectamente bien al útero.

Durante el preparto pueden registrarse contracciones tan intensas como las del parto y que sin embargo son absolutamente 
indoloras (Chassar Moir, 1939; Alvarez y Caldeyro, 1949; Vignes, 1951) porque no causan la dilatación del cuello. No dilatan el cue_ llo porque carecen del Triple Grandiente Descendente (Caldeyro Barcia y Alvarez. 1953).

Las contracciones del alumbramiento son tanto o más inten_ sas que las del parto, y sin embargo son absolutamente indoloras (Alvarez y Caldeyro Barcia, 1949), porque no causan distensión ni isquemia prolongada. Lo mismo podemos decir para las con. tracciones del post-alumbramiento. Estas se hacen dolorosas ("en. tuertos") cuando al expulsar loquios en úteros angulados, distien. den al orificio interno (Chassar Moir).

La hipertonía uterina (cuando es elevada) produce dolor porque causa isquemia prolongada del miometrio al comprimir sus vasos en forma permanente. 